JUSTYNA BIEDA - DOROTA WIŚNIEWSKA - JÓŹWIAK (Łódź)

\title{
Zasady dziedziczenia ustawowego na ziemiach Królestwa Polskiego po 1826 roku
}

I. Prawo spadkowe na ziemiach Królestwa Polskiego podlegało od $1808 \mathrm{r}$. regulacji Kodeksu Napoleona (dalej: KN), jak i od 1 stycznia 1826 r. Kodeksu Cywilnego Królestwa Polskiego (dalej: KCKP), który choć pozostawił w mocy dotychczas obowiązujące przepisy, zmienił jedynie zakres praw spadkowych małżonków ${ }^{1}$. Regulacje te obowiązywały na ziemiach centralnych Polskich, także po odzyskaniu niepodległości i zostały uchylone dopiero na mocy dekretu Prezydenta z dnia 8 października 1946 r.

Mimo iż formalnie przepisy KN i KCKP zostały uchylone ponad pół wieku temu, to nadal żyją one w praktyce sądowej. Obecnie toczy się wiele postępowań spadkowych dotyczących spadków otwartych przed 1947 r., w których należy stosować regulacje zawarte w przywołanych kodyfikacjach.

Niestety znajomość tych przepisów przez dzisiejszych prawników jest znikoma, co rodzi często problemy na gruncie konkretnych spraw sądowych. Tym bardziej że prawo spadkowe obwiązujące na ziemiach polskich od 1826 r. było skomplikowane, a wręcz niejasne w sytuacji, gdy do spadku dochodził małżonek i dzieci pozamałżeńskie.

Przedstawione studium ma na celu przypomnienie najważniejszych zasad dziedziczenia ustawowego obowiązujących w latach 1826-1946. Poruszono kwestie najczęściej występujące w toczących się dziś sprawach spadkowych wymagających uwzględnienia XIX-wiecznych przepisów.

II. Kodeks Napoleona dzielił dziedziców beztestamentowych na dwie grupy: tzw. spadkobierców porządkowych (prawych) i spadkobierców nieporządkowych. Różnica między nimi dotyczyła zasad odpowiedzialności za

${ }^{1}$ Art. 1 prawa przechodniego - Księga I oraz tytuł V i XVIII. Księgi III Kodeksu Cywilnego dotąd obowiązującego, na koniec Oddział 1. Działu V Prawa sejmowego z dnia 26 kwietnia 1818 roku, z końcem dnia 31. Grudnia 1825 roku w swey mocy ustaią, a w miejsce tych praw, Księga I Kodeksu Cywilnego Królestwa Polskiego i prawo osobne o przywilejach i hipotekach z dniem 1. Stycznia 1826 roku zaczną obowiązywać. 
długi spadkowe oraz momentu, w jakim mieli oni prawo objąć spadek w posiadanie $^{2}$. Spadkobiercy porządkowi odpowiadali za wszystkie długi i ciężary spadku, zaś spadkobiercy nieporządkowi, jedynie do wysokości majątku nabytego przez spadkobranie ${ }^{3}$. Ponadto, dziedzice prawi (porządkowi) z chwilą otwarcia spadku z mocy samego prawa, bez obowiązku dokonania jakichkolwiek formalności obejmowali spadek w posiadanie. W przeciwieństwie do dziedziców nieporządkowych, którzy musieli zwrócić się o wydanie majątku spadkowego do spadkobierców porządkowych lub sądu ${ }^{4}$. Do spadkobierców porządkowych KN zaliczał krewnych pochodzących z prawego łoża, takich jak zstępni, wstępni oraz dalsi krewni w linii bocznej, aż do dwunastego stopnia $^{5}$, zaś do grona spadkobierców nieporządkowych należał małżonek ${ }^{6}$, dzieci naturalne, rodzice naturalni, rodzeństwo naturalne i Skarb Państwa ${ }^{7}$.

$\mathrm{Z}$ chwilą wejścia w życie KCKP powstała istotna wątpliwość co do pozycji prawnej pozostającego przy życiu współmałżonka. O ile art. $767 \mathrm{KN}$ przyznawał małżonkowi prawo do spadku dopiero w razie braku krewnych do dwunastego stopnia i dzieci naturalnych, o tyle KCKP w sposób znaczący te uprawnienia rozszerzał, dopuszczając małżonka do dziedziczenia w zbiegu z zstępnymi i wstępnymi. Małżonek obok zstępnych i wstępnych uzyskał status dziedzica koniecznego, dla którego prawo zastrzegało określoną część spadku, ograniczając w ten sposób spadkodawcę w swobodzie dysponowania majątkiem na wypadek śmierci. Jednakże KCKP, stawiając $w$ jednym rzędzie małżonka z krewnymi prawymi, nie zaliczył go formalnie do grona spadkobierców porządkowych. Stąd też doktryna nadal traktowała małżonka jako spadkobiercę nieporządkowego. O ile należy się zgodzić, iż przy braku odpowiednich nowelizacji przepisów, małżonek lege artis pozostawał spadkobiercą nieporządkowym, o tyle rozwiązanie to było w sprzeczności z zasadami racjonalności, np. małżonek zazwyczaj znajdował się w posiadaniu pozostałego po zmarłym majątku, więc niewątpliwy obowiązek formalny wystąpienia do sądu o wprowadzenie w posiadanie tego mienia wydaje się pozbawiony zasad racjonalności.

III. 1. Kodeks Napoleona w art. $745 \mathrm{KN}$ powoływał do spadku dzieci z wyłączeniem innych krewnych ${ }^{8}$. Przy czym traktował na równi dzieci pra-

${ }^{2}$ J.J. Delsol, Zasady Kodeksu Napoleona w zwiazku z nauka i jurysprudencja, Warszawa 1874, s. $14-15$.

${ }^{3}$ Ibidem.

${ }^{4}$ Ibidem.

${ }^{5}$ J.K. Wołowski, Kurs kodeksu cywilnego, Warszawa 1868, s. 277.

${ }^{6}$ Dotychczasowe prawo nie przewidywało dziedziczenia małżonka w ogóle.

${ }^{7}$ W. Miszewska, Prawo cywilne, Warszawa 1927/28, s. 79.

${ }^{8}$ Art. $745 \mathrm{KN}$ - Dzieci lub ich zstępni dziedzicza po swoim ojcu i matce, dziadach, babach lub innych wstępnych, bez różnicy płci i pierworodztwa, a to chociażby z różnych pochodzity matżeństw. Dziedziczq w równych częściach i podług ilości głów, gdy są wszyscy w pierwszym stopniu 
we (zrodzone w małżeństwie), dzieci uprawnione, (legitymowane czyli dzieci osób stanu wolnego, które zawarły małżeństwo dopiero po narodzinach dziecka), jak i dzieci przysposobione ${ }^{9}$. Do spadku miały jednak prawo nie tylko same dzieci, ale także dalsi zstępni, jeżeli ich rodzice zmarli przed spadkodawcą. Pierwsi przychodzili do spadku w własnym imieniu, a drudzy tzw. prawem zastępstwa. Jednakże, o ile przyznawano prawo dziedziczenia dalszym zstępnym po dzieciach uprawnionych, o tyle odmawiano tego zstępnym dzieci przysposobionych, argumentując, iż stosunek przysposobienia zachodzi tylko między przysposobionym i przysposabiającym ${ }^{10}$.

Spadek dzielił się na tyle równych części, ile było dzieci, włączając dzieci zmarłe, o ile pozostało po nich potomstwo. Przy czym osoby przychodzące do spadku we własnym imieniu brały należną im część, natomiast dalsi zstępni otrzymywali jedynie do równego podziału udział przypadający temu kogo zastępowali ${ }^{11}$.

Na podstawie regulacji wprowadzonej przez KCKP udział spadkowy zstępnych ulegał zmianie, w sytuacji, gdy dochodzili oni do spadku z małżonkiem zmarłego ${ }^{12}$.

2. Wstępni spadkodawcy dochodzili do spadku tylko w razie braku zstępnych. Dziedziczenie wstępnych jest zagadnieniem skomplikowanym. Przede wszystkim KN dzielił wstępnych na klasę uprzywilejowaną, do której należeli matka i ojciec, oraz klasę nieuprzywilejowaną, tj. dalszych wstępnych. Dodatkowo, uprawnienia wstępnych w każdej z klas uzależnione były od kategorii krewnych, z którymi dochodzili do spadku, a także od pozostawania przy życiu współmałżonka zmarłego ${ }^{13}$.

2.1. Zakres udziałów spadkowych rodziców zmarłego uzależniony był od tego, czy dochodzili oni do spadku z rodzeństwem spadkodawcy lub ich zstępnymi. W myśl art. $748 \mathrm{KN}$ rodzice spadkodawcy dochodzący do spadku wspólnie z jego rodzeństwem lub ich zstępnymi, otrzymywali po 1/4 części spad$\mathrm{ku}^{14}$. Jeżeli natomiast nie było żyjącego rodzeństwa lub jego potomstwa każde

i powołani prawem własnem: biora spadek podtug szczepów, gdy przychodza wszyscy lub w części prawem zastępstwa.

${ }^{9}$ A. Gulczyński, Nazwisko dziecka. Ewolucje ukazywania relacji rodzinnoprawnych, Poznań 2010, s. 23.

${ }^{10}$ J.J. Delsol, op. cit., s. 32.

11 F. Podlewski, O spadkach i testamentach. Wyklad popularny prawa obowiazujacego z uwzględnieniem prawa rosyjskiego, austriackiego i niemieckiego, Warszawa 1900, s. 24-25.

${ }_{12}$ Te kwestie szczegółowo omawiamy w dalszej części artykułu, podobnie jak zbieg praw spadkowych dzieci prawych z dziećmi naturalnymi oraz wstępnych i małżonka.

${ }^{13}$ A. Okolski, Zasady prawa cywilnego obowiąujace w Królestwie Polskim, Warszawa 1885, s. 318-319.

${ }^{14}$ Art. $748 \mathrm{KN}$ - Gdyby ojciec i matka osoby, bezpotomnie zmarlej, przeżyly ja, i gdy ta pozostawila braci, siostry, lub ich zstępnych, spadek dzieli się na dwie równe części, z których polowa tylko przechodzi na ojca i matkę, i ci dziela się takowa między sobq zarówno. Druga połowa należy do braci, sióstr lub ich zstępnych, jak to będzie określone w Oddziale V niniejszego Działu. 
z rodziców spadkodawcy otrzymywało $1 / 2$ części masy spadkowej (art. 746 $\mathrm{KN})^{15}$. Gdy zaś przy życiu pozostawało tylko jedno z rodziców, otrzymywało ono swoją połowę spadku, zaś druga część przechodziła na wstępnych drugiej linii najbliższych stopniem lub w razie ich braku na dalszych krewnych bocznych. W sytuacji, gdy matka lub ojciec dochodzili do spadku z krewnymi bocznymi drugiej linii, oprócz swojej połowy spadku, otrzymywali 1/3 mająt$\mathrm{ku}$ z drugiej połowy w dożywotnie użytkowanie (art. $754 \mathrm{KN})^{16}$.

2.2. Dalsi wstępni byli powołani do dziedziczenia tylko w braku zstępnych, krewnych bocznych uprzywilejowanych, tj. braci i sióstr oraz rodziców, choć tylko w swojej linii. W razie braku wymienionych krewnych spadek przypadał $\mathrm{w}$ połowie dalszym wstępnym $\mathrm{w}$ linii macierzystej, a w połowie dalszym wstępnym w linii ojczystej, którzy wyłączali krewnych bocznych nieuprzywilejowanych w swojej linii ${ }^{17}$. Krewni w bliższym stopniu wyłączali dalszych, zaś podział między wstępnymi danej linii i w tym samym stopniu następował według liczby głów (art. $746 \mathrm{KN})^{18}$. Z powyższych zasad wynika, iż jeżeli spadkodawca pozostawił wstępnych w obu liniach, dziedziczyli oni całość spadku, którym dzielili się po połowie. Jeżeli natomiast pozostali jedynie wstępni z jednej linii, np. macierzystej, brali oni swoją połowę spadku, zaś druga część przypadała krewnym bocznym nieuprzywilejowanym z linii ojczystej (art. $153 \mathrm{KN})^{19}$. Dopiero w sytuacji, gdyby w linii ojczystej nie było krewnych bocznych w stopniu uprawniającym do spadkobrania, całość masy przypadłaby wstępnym macierzystym $(\text { art. } 755 \mathrm{KN})^{20}$.

2.3. Omawiając kwestie dotyczące praw spadkowych wstępnych, odrębnie należy przedstawić zagadnienie dotyczące tzw. prawa powrotu spadkowego. Zgodnie z art. $747 \mathrm{KN}$ w razie bezpotomnej śmierci spadkodawcy wstępni (zarówno rodzice, jak i dalsi wstępni) mieli prawo do objęcia swą częścią przedmiotów, które uprzednio spadkodawca otrzymał od nich w drodze darowizny $^{21}$. Jednakże uprawnienie to przysługiwało wstępnym tylko jeżeli mają-

${ }^{15}$ Art. $746 \mathrm{KN}$ - Jeżeli spadkodawca nie zostawil ani potomstwa, ani brata, ani siostry, ani zstępnych tychże, spadek dzieli się po połowie pomiędzy wstępnych linii ojczystej $i$ wstępnych linii macierzystej. Wstępny w stopniu najbliższy, otrzymuje połowę przypadająca dla jego linii, z wyłaczeniem wszystkich innych. Wstępni tego samego stopnia dziedzicza podlug ilości głów.

${ }^{16}$ Art. $754 \mathrm{KN}$ - W przypadku przewidzianym przez artykut poprzedzający, ojciec lub matka przy życiu pozostali, mają użytkowanie trzeciej części majątku, jakiego na własność nie odziedziczaja.

${ }^{17}$ M. Planiol, O spadkach, autoryzowany przektad pod redakcją J. Namietkiwicza, Warszawa 1927, s. 41.

${ }^{18}$ F. Podlewski, op. cit., s. 28-29.

${ }^{19}$ J.K. Wołowski, op. cit., s. 323-324.

${ }^{20}$ C. Demolombe, O spadkach. Przełożyt i uzupetnit przepisami Kodeksu Cywilnego z 1825 r. oraz jurysprudencja b. IX Departamentu Rzadzacego Senatu, Warszawskiej Izby Sadowej i Kasacyjnego Departamenty Senatu Władysław Nowakowski, t. I, Warszawa 1900, s. 221.

${ }^{21}$ Art. $747 \mathrm{KN}$ - Wstepni, z wyłaczeniem wszystkich innych, odziedziczaja przedmioty darowane przez nich dzieciom, lub ich zstępnym zmartym bezpotomnie, gdy przedmioty darowane znajduja 
tek darowany znajdował się w masie spadkowej lub został zbyty, w tym ostatnim przypadku wstępni mieli prawo żądać zwrotu uzyskanej sumy sprzedaży. $\mathrm{Z}$ powyższego wynika, iż prawo powrotu nie służyło wstępnym na wypadek zniszczenia przedmiotu darowizny, choćby z winy obdarowanego. Nie mogli oni także żądać wynagrodzenia za pogorszenie darowanego majątku ${ }^{22}$.

Motywem regulacji według A. Okolskiego „było przypuszczenie, iż zamiarem wstępnego, czyniącego darowiznę, było wzbogacenie tylko swoich zstępnych, nie zaś osób, któreby w razie bezpotomnego ich zejścia mogły być powołane do spadku"23.

2.3.1. Do grona krewnych bocznych uprzywilejowanych zaliczano rodzeństwo spadkodawcy lub ich zstępnych. Przychodzili oni do spadku w razie braku zstępnych, wyłączając dalszych krewnych bocznych, jak i wstępnych nieuprzywilejowanych. Zatem w razie braku rodziców spadkodawcy rodzeństwo otrzymywało całość spadku. Jeżeli bracia i siostry dziedziczyli wspólnie $\mathrm{z}$ rodzicami zmarłego, przypadała im w udziale połowa masy spadkowej. Gdy zaś przy życiu pozostawało tylko jedno z nich, rodzeństwu przypadało $3 / 4$ majątku (art. $751 \mathrm{KN})^{24}$.

Podział części spadku przypadającej rodzeństwu odbywał się według zasad określonych w art. $752 \mathrm{KN}$. I tak, jeżeli bracia i siostry pochodzili z tego samego małżeństwa, część spadku na nich przypadająca dzieliła się na równe części, według liczby głów. Gdy zaś krewni boczni uprzywilejowani pochodzili z różnych małżeństw, tj. w sytuacji dojścia do spadku prócz braci i sióstr rodzonych także rodzeństwa przyrodniego, czy to ze strony ojca, czy matki, udział spadkowy im przypadający dzielił się między dwie linie (ojczystą i macierzystą). Bracia i siostry rodzeni otrzymywali schedę w obu liniach, zaś rodzeństwo przyrodnie tylko w jednej. W ramach zaś danej linii podział następował według liczby głów. Natomiast w sytuacji istnienia tylko rodzeństwa w jednej linii, otrzymywało ono całość udziału spadku z wyłączeniem wszystkich krewnych w drugiej linii ${ }^{25}$.

2.3.2. Zgodnie $\mathrm{z}$ art. $753 \mathrm{KN}$ krewni boczni nieuprzywilejowani, aż do dwunastego stopnia włącznie, dochodzili do spadku dopiero w razie braku

się w naturze w pozostałości spadkowej. Jeżeli przedmioty zostały zbyte, wstępni otrzymuja cenę, jakaby za nie przypadata. Odziedziczaja także skarge o zwrot, jakaby obdarowanemu stużła.

${ }^{22}$ A. Okolski, op. cit., s. 321-322.

${ }^{23}$ Ibidem, s. 321.

${ }^{24}$ Art. $751 \mathrm{KN}$ - Jeżeli ojciec i matka osoby bezpotomnie zmarlej, oręż przeżyli, jej bracia, siostry lub ich zstępni, powołani sa do polowy tylko spadku. Jeżeli tylko ojciec lub matka przeżyli, powolani sa do dziedziczenia w trzech czwartych częściach.

${ }^{25}$ Art. $752 \mathrm{KN}$ - Podziat połowy lub trzech czwartych części, przypadajacych dla braci lub sióstr, podlug osnowy artykułu poprzedzającego, uskutecznia się pomiędzy niemi w równych częściach, jeżeli wszyscy sa z tego samego toża: a jeżeli sa z różnego toża, podziat uskutecznia się po połowie między dwie linie spadkodawcy, ojczysta i macierzystą; rodzeni maja udziat w obudwóch liniach, przyrodni zaś, czy to z ojca, czy z matki, każdy w swojej tylko linii; jeżeli z jednej tylko strony sa bracia lub siostry, dziedzicza całość, z wyłączeniem wszystkich innych krewnych drugiej linii. 
zstępnych, krewnych bocznych uprzywilejowanych (czyli braci i sióstr), rodziców, a nawet wstępnych nieuprzywilejowanych. Przy czym wstępni wyłączali krewnych bocznych nieuprzywilejowanych tylko w swojej linii ${ }^{26}$.

Spadek przechodzący na spadkobierców pobocznych zawsze dzielił się na dwie części. Jedna przypadała krewnym z linii ojczystej, a druga krewnym macierzystym. Przy czym bliższy stopniem wyłączał dalszego, tak więc nie miała tu zastosowania zasada zastępstwa. Jeżeli było kilku krewnych tego samego stopnia, podział następował według liczby głów ${ }^{27}$. Mogło się zdarzyć, iż w jednej linii do spadku dochodzili krewni np. trzeciego stopnia, a w drugiej dopiero np. dziesiątego. Dopiero gdy w którejkolwiek linii zabrakło krewnych do dwunastego stopnia, przypadająca im część spadku przechodziła na najbliższych krewnych w drugiej linii ${ }^{28}$.

IV. 1. Kwestia praw spadkowych współmałżonka pozostałego przy życiu jest zagadnieniem niezwykle skomplikowanym, gdyż trzeba je rozpatrywać na gruncie pozostających ze sobą w sprzeczności regulacji zawartych zarówno w KN, jak i w KCKP.

Kodeks Napoleona prawa spadkowe opierał przede wszystkim na więzach krwi. W związku z powyższym nie zaliczał małżonka do grona dziedziców koniecznych, czego wyraz daje art. $916 \mathrm{KN}$ stanowiący, iż „w braku wstępnych i zstępnych szczodrobliwości przez akty między żyjącymi lub testamentowe mogą wyczerpać całość spadku".

Natomiast KCKP, przyjmując za zasadę domniemany zamiar spadkodawcy, który bardziej przywiązany do swego małżonka aniżeli do dalekich krewnych, chce zabezpieczyć byt współmałżonka, wprowadził w art. 232-235 regulacje nadające małżonkowi status dziedzica koniecznego, ale wielkość udziału spadkowego należna małżonkowi uzależniona została od kategorii krewnych, z jakimi dochodził on do spadku.

Prawa spadkowe małżonka dziedziczącego z mocy ustawy wraz z zstępnymi zostały określone w art. $232 \mathrm{KCKP}$. Zgodnie z tym przepisem:

„małżonkowi przy życiu pozostałemu, należy się po współmałżonku zmarłym, część spadku równa części, jaka na każde dziecko przypada, licząc pozostałego małżonka przy podziale spadku za jedno dziecko i zostawiając onemuż wybór między częściami. Część na małżonka przypadła służyć mu tylko będzie do użytkowania dożywotniego".

${ }^{26}$ Art. $753 \mathrm{KN}$ - Gdy nie ma braci lub sióstr, albo ich zstepnych, $i$ w braku wstęnych w jednej lub drugiej linii, spadek przechodzi w polowie na wstepnych przy życiu pozostałych, a w drugiej połowie na najbliższych krewnych drugiej linii. W zbiegu krewnych pobocznych tego samego stopnia, podzial nastęuje podtug ilości głów.

27 J.J. Delsol, op. cit., s. 37.

${ }^{28}$ F. Podlewski, op. cit., s. 32. 
$\mathrm{Na}$ gruncie art. 232 KCKP powstał problem sposobu obliczania części ustawowej należnej małżonkowi. Brzmienie art. 232 KCKP pozwala na przyjęcie dwóch interpretacji.

Pierwsza, przyjmowana przez F. Flamma ${ }^{29}$, zakładała, iż małżonka należało traktować jak dodatkowe dziecko. Rozumowanie takie w konsekwencji mogło prowadzić do ustalenia części ustawowej większej, aniżeli wynikałoby to $\mathrm{z}$ liczby posiadanych dzieci, $\mathrm{z}$ jednoczesnym pokrzywdzeniem zstępnych. Np. gdy testator pozostawił dziecko i małżonka, to część ustawowa wynosiłaby nie połowę spadku, jakby na to wskazywała liczba dzieci, ale $2 / 3$ majątku. Jednakże dziecko zostałoby ograniczone w swych prawach, gdyż zamiast $1 / 2$ majątku, otrzymałoby $1 / 3$.

Odmienne stanowisko prezentowali F. Podlewski ${ }^{30}$, C. Demolombe ${ }^{31}$, czy L. Bobiński ${ }^{32}$. Uważali oni, iż małżonka nie można traktować jako dodatkowe dziecko, tylko należy obliczyć rzeczywistą część ustawową wynikającą z liczby posiadanych dzieci, a następnie taką samą schedę przyznać małżonkowi na dożywotnie użytkowanie. Jeśli więc testator pozostawił jedno dziecko i małżonka, to część ustawowa zastrzeżona dla dziecka będzie stanowiła połowę spadku, a na drugiej połowie małżonek będzie miał prawo dożywotniego użytkowania. Jak pisze F. Podlewski, część zastrzeżona dla małżonka zmniejsza część rozrządzalną spadku, a fakt dojścia do spadku małżonka nigdy nie powinien wpływać na wysokość części zastrzeżonej dla zstępnych ${ }^{33}$.

Druga z zaprezentowanych koncepcji wydaje się zasadniejsza, z uwagi na treść art. $913 \mathrm{KN}$, który uzależniał część spadku zastrzeżoną dla dzieci jedynie od liczby potomstwa. Małżonek traktowany jak dodatkowe dziecko powodowałby umniejszenie praw rzeczywistych dzieci.

W literaturze przyjmowano, iż art. 232 KCKP określał jedynie prawa spadkowe małżonka pozostającego przy życiu, gdy dochodził do spadku w zbiegu z dziećmi prawymi spadkodawcy. Natomiast trudno na tej podstawie określić zakres praw spadkowych małżonka, w zbiegu z dziećmi naturalnymi. Doktryna zajmuje trzy stanowiska.

F. Flamm jako jedyny uważał, iż w przypadku zbiegu praw małżonka z dziećmi naturalnymi, małżonek powinien otrzymać jedynie na dożywotnie użytkowanie taką część majątku, jaką by dostał, gdyby zamiast dzieci naturalnych istniały dzieci prawe ${ }^{34}$. Jego zdaniem, w braku krewnych w stopniu spadkowym, dziecko naturalne ma takie prawa jak dziecko prawe, zatem ist-

${ }^{29}$ F. Flamm, O prawach spadkowych dziecka naturalnego niemniej o zbiegu praw matżonka ze spadkobiercami, tudzież krewnymi naturalnemi wspólmatżonka, Warszawa 1865, s. 9.

${ }^{30}$ F. Podlewski, op. cit., s. 125.

${ }^{31}$ C. Demolombe, op. cit., s. 200.

${ }^{32}$ L. Bobiński, O testamentach i o pisaniu testamentów, Warszawa 1901, s. 16.

${ }^{33}$ F. Podlewski, op. cit., s. 125.

${ }^{34}$ F. Flamm, op. cit., s. 21. 
nienia małżonka nie może tych praw zmieniać, inaczej niż to wynika $\mathrm{z}$ treści art. $232 \mathrm{KCKP}^{35}$.

J.K. Wołowski stanął na stanowisku, iż, gdy do spadku dochodzą dzieci naturalne i małżonek, ten ostatni w przypadku dziedziczenia ustawowego powinien dostać na własność połowę spadku. Wywodził on, iż

„byłoby najprostszą rzeczą, przyznać małżonkowi z dziećmi naturalnymi też same prawa, jakie im nadaje Kodeks Polski w zbiegu z dziećmi prawemi, to jest część dziecka na dożywocie, ale dzieci naturalnych prawo nigdy nie kładzie na tej samej linii jak dzieci prawe, a obok tego doszlibyśmy do tego szczególnego rezultatu, że małżonek byłby w gorszym położeniu w braku zupełnym krewnych, jak wtenczas gdy są krewni do dwunastego stopnia. Mniemam przeto, iż małżonek, w takim przypadku nie może mieć mniej jak połowę spadku na własność"36.

\section{Zdanie to podzielał również A. Okolski twierdzący, iż}

„W braku wyraźnego przepisu prawa należy przyjść do wniosku, iż pozostały przy życiu małżonek nie może posiadać gorszych praw, jakieby miał, przychodząc do spadku z najmniej uprzywilejowanymi. Ponieważ zaś wtedy otrzymuje połowę spadku, takie samo więc prawo powinien mieć, przychodząc do spadku z samem tylko dziedzicem naturalnym" 37 .

Natomiast Preiss ${ }^{38}$, Filipski ${ }^{39}$, Demolombe ${ }^{40}$ twierdzili, iż małżonek dziedziczący z mocy ustawy $\mathrm{w}$ zbiegu $\mathrm{z}$ dziećmi naturalnymi powinien dostać 1/4 spadku na własność. Filipski słusznie zauważył, iż dziecko naturalne jest krewnym spadkodawcy pierwszego stopnia, ale tylko krewnym naturalnym, niemającym jednakże praw dziedzica prawego, dlatego też zasadnym jest przyznanie małżonkowi takiej części spadku, jak należy mu się, jeżeli dochodzi do spadku z krewnymi pierwszych czterech stopni, a więc $1 / 4$ spadku na własnośćc ${ }^{41}$.

Prawa spadkowe małżonka dochodzącego z mocy ustawy do spadku jedynie z dalszymi krewnymi współmałżonka określał art. 233 KCKP. Stanowił on, iż

,jeżeli dzieci nie ma, a znajdują się krewni zmarłego małżonka aż do czwartego stopnia włącznie, pozostały współmałżonek mieć będzie czwartą część spadku

\footnotetext{
${ }^{35}$ Ibidem s. 20.

${ }^{36}$ J.K. Wołowski, op. cit., s. 345.

${ }^{37}$ A. Okolski, op. cit., s. 326.

38 „Gazeta Sądowa”, nr 153, 1884, s. 236.

39 „Przegląd Sądowy”, t. XVII, s. 364.

${ }^{40}$ C. Demolombe, op. cit., s. 205.

41 „Przegląd Sądowy”, t. XVII, s. 364.
} 
na własność. Gdy by zaś i do tego stopnia krewnych nie było, połowa spadku prawem własności do pozostałego małżonka należeć będzie. W jakim przypadku cały majątek po zmarłym małżonku przechodzi na własność do pozostałego przy życiu - współmałżonka, przepisanym jest w Tytule o spadkach”.

Mając na względzie treść art. 233 KCKC, część spadku należna małżonkowi w przypadku istnienia krewnych do czwartego stopnia wynosiła $1 / 4$ schedy, a do dwunastego stopnia $1 / 2$, który to majątek uprawniony otrzymywał na własność. Natomiast gdyby nie było takich krewnych ani dzieci naturalnych, zgodnie z art. $767 \mathrm{KN}$ małżonek przy dziedziczeniu ustawowym otrzymywał cały spadek ${ }^{42}$.

2.1.1. Dziecko naturalne było to dziecko zrodzone z wolnego mężczyzny i niezamężnej kobiety ${ }^{43}$. KN dzielił dzieci naturalne na prawnie uznane i nieuznane. Dziecko naturalne nieuznane nie posiadało w ogóle praw do spadku ${ }^{44}$. Zgodnie z art. $757 \mathrm{KN}$ wielkość części spadkowej należnej dziecku naturalnemu uznanemu uzależniona była od kategorii krewnych, z jakimi dochodziło ono do spadku ${ }^{45}$. W przypadku, gdy dziecko naturalne dochodziło do spadku z zstępnymi prawymi w myśl art. $757 \mathrm{KN}$ miało ono prawo do ,jednej trzeciej części udziału spadkowego, jaki by miało dziecko naturalne, gdyby było prawem".

W literaturze powstał spór co do sposobu obliczania części ustawowej należnej dziecku naturalnemu. Dostrzegamy dwa stanowiska:

1. prezentowane między innymi przez Dudkiewicza ${ }^{46}$ i Barwińskiego ${ }^{47}$ zakładało, iż z treści art. $757 \mathrm{KN}$ wynika, że część dziecka naturalnego równa jest $1 / 3$ części dziecka prawego. Dla zobrazowania tej koncepcji posłużmy się przykładem. Jeśli spadkodawca pozostawia po sobie dwoje dzieci prawych i jedno naturalne, to w myśl prezentowanego poglądu najpierw należy określić część ustawową uwzględniając tylko dzieci prawe.

${ }^{42}$ Art. $767 \mathrm{KN}$ - Gdy zmarty nie zostawia ani krewnych w stopniu dajacym prawo do spadku, ani dzieci naturalnych, majątek po nim spadkowy należy do pozostatego przy życiu matżonka nie rozwiedzionego.

${ }^{43}$ S. Płaza, Historia prawa w Polsce na tle porównawczym, cz. II, Kraków 2002, s. 66.

${ }^{44}$ Art. $756 \mathrm{KN}$ - Dzieci natura'lne nie sa dziedzicami: ustawa nadaje im tylko prawo do majatku po zmarlym ich ojcu lub matce, gdy sa prawnie uznanemi. Nie nadaje im żadnego prawa do majatku po krewnych ich ojca lub matki.

${ }^{45}$ Art. $757 \mathrm{KN}$ - Prawa dziecka naturalnego do majątku po jego ojcu lub matce zmartych, urzadzaja się w sposób następujacy. Jeżeli ojciec lub matka pozostawili zstępnych prawych, prawo to stuży do jednej trzeciej części udziału spadkowego, jakiby miato dziecko naturalne, gdyby byto prawem; do połowy, gdy ojciec lub matka nie pozostawiaja zstepnych, lecz tylko wstepnych, albo też braci lub siostry; do trzech czwartych części, gdy ojciec lub matka nie pozostawiaja ani zstępnych, ani wstepnych, ani braci, ani sióstr.

${ }^{46}$ F. Dudkiewicz, Prawo hipoteczne, s. 366.

${ }^{47}$ E.J. Barwiński, Prawo spadkowe obow. w b. Królestwie Polskim w zarysie, Warszawa 1938, s. 82 . 
Zgodnie z art. $913 \mathrm{KN}$, wynosiłaby ona $2 / 3$ spadku, czyli każde z dzieci dostałoby po $1 / 3$. Następnie z tak wyliczonego udziału należy wydzielić $1 / 3$, aby uzyskać część przypadającą dziecku naturalnemu, która w omawianym przykładzie wynosiłaby $1 / 9$ spadku;

2. przyjmowane zdecydowanie częściej (Flamm ${ }^{48}$, Schoenwitz $^{49}$, Demolom$b^{50}$ ), zakładało rozumowanie odmienne, oparte na założeniu, iż dziecko naturalne w świetle art. $757 \mathrm{KN}$ nie stanowi bezwzględnej frakcji dziecka prawego. Jak podaje Demolombe, prawidłowe rozumienie art. $757 \mathrm{KN}$ nakazuje przy wydzielaniu części ustawowej uważać dziecko naturalne za prawe i liczyć tak, jak gdyby dzieci prawych było o jedno więcej. Następnie z tak obliczonego udziału należy wyodrębnić $1 / 3$, aby uzyskać część przypadającą dziecku naturalnemu ${ }^{51}$. Zgodnie $\mathrm{z}$ omawianą teorią, gdy na przykład spadkodawca pozostawia troje dzieci prawych, to w myśl art. $913 \mathrm{KN}$ część obowiązkowa wynosi 3/4, co z kolei prowadzi do wniosku, iż każde dziecko prawe dostałoby po $1 / 4$ spadku, a dziecko naturalne $1 / 3$ z $1 / 4$, czyli $1 / 12$ schedy.

Wydaje się, iż pierwsze z zaprezentowanych stanowisk nie jest prawidłowe, bo oparte zostało na błędnej interpretacji art. $757 \mathrm{KN}$. W przepisie tym ustawodawca wyraźnie wskazał, iż dziecku naturalnemu służy prawo do $1 / 3$ części udziału, jaką by miało to dziecko, gdyby było prawym, a nie do 1/3 części udziału dziecka prawego.

W myśl art. $757 \mathrm{KN}$, jeżeli brak było zstępnych prawych, a dziecko naturalne dochodziło do spadku z wstępnymi lub też rodzeństwem spadkodawcy, miało ono prawo do połowy udziału spadkowego, jaki by otrzymało gdyby było prawe. Jeżeli dziecko naturalne byłoby prawe, to zgodnie z art. $913 \mathrm{KN}$ otrzymałoby cały spadek. W związku z powyższym część spadku dziecka naturalnego dochodzącego do spadkobrania $\mathrm{z}$ wstępnymi lub rodzeństwem testatora stanowiła $1 / 2$ schedy.

W przypadku natomiast, gdy pozostawali przy życiu jedynie dalsi krewni spadkodawcy, art. $757 \mathrm{KN}$ zastrzegał dla dziecka naturalnego 3/4 udziału spadkowego, jaki by mu przypadał gdyby było prawe. Podobnie jak poprzednio, dziecku prawemu należałby się cały spadek. W związku z czym dziecko naturalne powinno otrzymać 3/4 pozostałego majątku.

Przy czym, zgodnie z art. $760 \mathrm{KN}$, dziecko naturalne obowiązane było zaliczyć na poczet należnej mu części spadku wszelkie otrzymane od rodziców darowizny. Powodem takiej regulacji była najprawdopodobniej chęć zabez-

${ }^{48}$ F. Flamm, op. cit., s. 6.

${ }^{49} \mathrm{~F}$. Schoenwitz, O zbiegu praw spadkowych przy życiu pozostatego wspótmatżonka z prawami spadkowymi dzieci naturalnych. Interpretacja artykułów 232 i 233 Kodeksu Cywilnego Królestwa Polskiego i artykułu 757 Kodeksu Napoleona, Warszawa 1913, s. 8.

${ }^{50}$ C. Demolombe, op. cit., s. 55.

${ }^{51}$ Ibidem. 
pieczenia interesów rodziny prawej i zapobieżenie obchodzeniu przepisów spadkowych przez czynienie szczodrobliwości za życia ${ }^{52}$.

Jeżeli zmarły nie pozostawił ani krewnych w stopniu dającym prawo do spadku, ani małżonka, dziecko naturalne prawnie uznane dziedziczyło cały majątek (art. $758 \mathrm{KN})^{53}$.

Uprawnienia spadkowe dziecka naturalnego na mocy art. $761 \mathrm{KN}$ mogły zostać przez rodzica ograniczone o połowę ${ }^{54}$. Jednakże, by decyzja taka była skuteczna, musiały zostać spełnione pewne warunki.

Po pierwsze, dziecko już za życia rodzica musiało otrzymać połowę tego, co by mu się należało po jego śmierci. Z uwagi na fakt, iż rzeczywista wartość należnego udziału mogła zostać określona dopiero po śmierci spadkodawcy, dziecko naturalne, jeżeli dostało mniej, miało prawo żądać uzupełnienia tej połowy, natomiast wtedy gdy otrzymało więcej aniżeli połowę należnej schedy, zatrzymywało nadwyżkę, o ile nie przekraczała ona praw wynikających $\mathrm{z}$ art. $757 \mathrm{KN}^{55}$.

Ponadto, ojciec lub matka musieli wyraźnie oświadczyć, że ich zamiarem jest ograniczenie praw dziecka naturalnego. Na tym gruncie powstał problem, czy oświadczenie takie rodzic mógł złożyć w akcie ostatniej woli. A. Okolski wywodził, iż ponieważ udział dziecka naturalnego musiał być wydzielony za życia matki lub ojca, to niedopuszczalnym jest, aby oświadczenie to mogło zostać złożone dopiero $\mathrm{w}$ testamencie, lecz powinno ono zostać dokonane wcześniej w akcie darowizny ${ }^{56}$. F. Podlewski natomiast nie widział przeszkód do złożenia takiego oświadczenia w akcie ostatniej woli ${ }^{57}$.

Skłaniamy się ku twierdzeniu ostatniego autora. Z treści art. $761 \mathrm{KN}$ w żadnym razie nie wynika, że oświadczenie o ograniczeniu praw spadkowych dziecka naturalnego musiało być złożone przez rodzica w akcie darowizny. Nie istniały żadne prawne przeszkody, by decyzję o ograniczeniu praw dziecka naturalnego, rodzic podejmował dopiero przy spisywaniu testamentu, mając świadomość, iż już wcześniej dziecko naturalne dostało od niego połowę udziału, który by mu po jego śmierci z ustawy przypadał.

2.1.2. Zstępni dziecka naturalnego prawnie uznanego mogli dziedziczyć po jego rodzicach prawem zastępstwa (art. $759 \mathrm{KN})$. Mogli też dochodzić do

${ }^{52}$ Art. $760 \mathrm{KN}$ - Dziecko naturalne, lub jego zstępni, obowiązani sq zaliczyć na rzecz tego, co im z prawa należy, wszystko to, co otrzymali od ojca lub matki, po których się spadek otworzyl, $i$ coby ulegato powrotowi, podlug prawideł w Oddziale II Działu VI niniejszego Tytułu objętych.

${ }^{53}$ F. Flamm, op. cit., s. 33.

${ }^{54}$ Art. $761 \mathrm{KN}$ - Wszelkie poszukiwanie jest im wzbronione, gdy otrzymaty za życia ojca swojego lub matki, połowę tego, co im artykuły poprzedzające zapewniaja, z wyraźnem ze strony ich ojca lub matki oświadczeniem, że zamiarem ich jest ograniczyć dziecko naturalne do udziału, jaki mu wyznaczyli.

${ }^{55}$ A. Okolski, op. cit., s. 327.

${ }^{56}$ Ibidem.

${ }^{57}$ F. Podlewski, op. cit., s. 43. 
spadku na mocy własnego prawa, jeżeli dziecko naturalne zostało uznane za niegodne lub też odrzuciło spadek. W literaturze przeważa pogląd, iż z wskazanych uprawnień mogli korzystać tylko zstępni prawi dziecka naturalnego. Jak podaje M. Planiol,

„Przepis 759 może przynieść korzyść tylko zstępnym prawym dziecka naturalnego, chociaż przepis pod tym względem nie wypowiada się wyraźnie, mówi bowiem o tem w sposób niejasny, niema zastosowania do dzieci naturalnych dziecka naturalnego. Są oni wyłączeni przez art. 756 według którego »Ustawa nie nadaje dzieciom naturalnym żadnego prawa do majątku po krewnych ich ojca lub matki«. Nie będąc powołanymi prawem własnem do spadku, tem bardziej nie mogą oni zastępować w nim swego naturalnego ojca lub naturalnej matki”58.

2.2. W myśl art. $765 \mathrm{KN}$ rodzice dziecka naturalnego bezpotomnie zmarłego mają prawo do spadku po nim, o ile zostało ono przez nich prawnie uznane. Otrzymują oni całość lub połowę spadku, w zależności od tego, czy spadkodawca był uznany prawnie przez oboje rodziców, czy tylko przez jednego ${ }^{59}$. Zaznaczmy, iż art. $765 \mathrm{KN}$ nie przewidywał praw spadkowych dla dalszych wstępnych naturalnych, choć wnuki naturalne po swych dziadkach naturalnych dziedziczyły. Rozwiązanie to należy uznać za wynik uchybienia legislacyjnego, gdyż analiza przepisów KN wskazuje, że ustawodawca oparł regulacje praw spadkowych na zasadzie wzajemności ${ }^{60}$.

Trudny do rozstrzygnięcia okazuje się problem praw spadkowych rodziców naturalnych, gdy wraz z nimi do spadku po dziecku naturalnym dochodził małżonek. KCKP regulował prawa spadkowe małżonka w zbiegu z krewnymi prawymi. Nie znajdziemy zaś w przepisach rozstrzygnięcia, jak winny kształtować się prawa rodziców naturalnych, jeżeli pozostawał przy życiu małżonek dziecka naturalnego. Zagadnienie to pozostawało również poza zainteresowaniem literatury.

Przy braku regulacji prawnych i poglądów doktryny koncepcji można by wysunąć wiele opinii. W tym miejscu przedstawiamy dwie, które wydają się najbardziej racjonalne.

Przy założeniu, iż rodziców naturalnych potraktujemy jak prawych, zgodnie z treścią art. 233 KCKP małżonek otrzymałby 1/4 części spadku, a rodzice naturalni $3 / 4$ majątku. Jednakże ta koncepcja nie jest do końca przekonująca z uwagi na fakt, iż krewnych naturalnych XIX-wieczny ustawodawca nigdy nie stawiał na równi z krewnymi prawymi.

${ }^{58}$ M. Planiol, op. cit., s. 42.

${ }^{59}$ Art. $765 \mathrm{KN}$ - Spadek po dziecku naturalnem, zmarlem bezpotomnie, przechodzi na tego z rodziców, które je uznało, albo po połowie na oboje rodziców, jeżeli uznane zostało przez jednego i drugiego.

${ }^{60}$ M. Planiol, op. cit., s. 53-54. 
Drugie możliwe rozstrzygnięcie sięga do wykładni art. 233 KCKP w związku z art. $767 \mathrm{KN}$. Pierwszy z tych przepisów określa prawa spadkowe małżonka $\mathrm{z}$ krewnymi prawymi do dwunastego stopnia. Zdanie drugie stanowi, iż „w jakim przypadku cały majątek po zmarłym małżonku przechodzi na własność do pozostałego przy życiu współmałżonka, przepisanym jest w Tytule o spadkach". I tak w Księdze III, tytule I, Dziale IV, oddziale II KN odnajdujemy art. 767, który mówi: „gdy zmarły nie zostawia ani krewnych w stopniu dającym prawo spadku, ani dzieci naturalnych, majątek po nim spadkowy należy do pozostałego przy życiu małżonka nie rozwiedzionego". Art. 767 KN wyraźnie wskazuje, iż jedynymi krewnymi naturalnymi mającymi prawo do spadku w zbiegu z małżonkiem są dzieci naturalne. Stąd też można wyprowadzić wniosek, iż ustawodawca pozbawił rodziców naturalnych prawa do spadku po ich dziecku naturalnym, jeżeli przy życiu pozostawał małżonek zmarłego.

2.3. Rodzeństwo dziecka naturalnego dochodziło do spadku na wypadek wcześniejszej śmierci rodziców. W tym wypadku prawa spadkowe kształtowały się odmiennie w stosunku do rodzeństwa naturalnego i prawego ${ }^{61}$.

Bracia i siostry prawe dziecka naturalnego zgodnie z art. $766 \mathrm{KN}$ dziedziczyły jedynie przedmioty darowane uprzednio zmarłemu przez wspólnych rodziców naturalnych lub jednego z nich, o ile znajdowały się jeszcze w masie spadkowej. Ewentualnie nabywali oni roszczenie o zwrot rzeczy, o ile przysługiwało ono spadkodawcy, lub też mieli prawo do odebrania ceny w razie zbycia rzeczy na wypadek, gdyby nie została ona jeszcze zapłacona ${ }^{62}$. Ponadto zaznaczmy, iż prawa te na wypadek wcześniejszej śmierci brata lub siostry z prawego łoża nie przechodziły na zstępnych tych ostatnich ${ }^{63}$. Zaś prawo do całej reszty pozostałego majątku nabywało rodzeństwo naturalne bądź na wypadek wcześniejszej śmierci tych ostatnich ich zstępni prawi.

Postawienie w lepszej sytuacji rodzeństwa naturalnego niż braci i sióstr prawych uzasadniano chęcią polepszenia sytuacji majątkowej rodzeństwa naturalnego, znajdującego się w gorszej sytuacji niż rodzeństwo prawe i nieposiadającego żadnych praw do majątków rodzinnych ${ }^{64}$.

Podobnie jak w poprzednim przypadku nasuwa się pytanie o prawa spadkowe rodzeństwa dziecka naturalnego w sytuacji pozostawania przy życiu małżonka tego ostatniego. Odpowiedzi na to pytanie, tak jak o rodziców naturalnych, nie znajdziemy ani w ustawodawstwie, ani w doktrynie.

${ }^{61}$ A. Okolski, op. cit., s. 329.

${ }^{62}$ Art. $766 \mathrm{KN}$ - W przypadku wcześniejszej śmierci ojca i matki dziecka naturalnego, majątki, jakie od nich otrzymato, przechodza na braci lub siostry prawe, jeżeli te majątki znajduja się w naturze w pozostałości: skargi o zwrot, jeżeli stużą, albo cena tych majątków, gdy byty zbyte, o ile się jeszcze należy, wracają również do braci i sióstr prawych. Wszystkie inne majątki przechodza na braci i siostry naturalne, albo na ich zstępnych.

${ }^{63}$ J.J. Delsol, op. cit., s. 51.

${ }^{64}$ F. Podlewski, op. cit., s. 52. 
W stosunku do rodzeństwa prawego wydaje się, iż należy zachować ich prawa spadkowe wynikające $\mathrm{z}$ art. $766 \mathrm{KN}$, tj. do przedmiotów darowanych dziecku naturalnemu przez ich wspólnych rodziców lub jednego z nich, o ile wartość tych przedmiotów nie przekroczy praw spadkowych małżonka określonych w art. 233 KCKP (udział spadkowy małżonka dziedziczącego z rodzeństwem prawym spadkodawcy wynosi $1 / 4$ spadku).

Natomiast zgodnie z treścią rozważanego powyżej art. $767 \mathrm{KN}$ rodzeństwu naturalnemu pozostałemu po dziecku naturalnym, a dochodzącego do spadku w zbiegu z małżonkiem tego ostatniego należy odmówić praw spadkowych, jako krewnym nieujętym w treści tegoż przepisu.

2.4. W braku dziedziców ustawowych spadek przypadał Skarbowi Państwa jako wakujący i bezdziedziczny (art. $768 \mathrm{KN}$ ). Państwo w tym przypadku nie jest jednak dziedzicem po zmarłym na mocy powołania spadkowego, a tylko wykonuje swoje prawa zwierzchnie. Gdy spadek nabywało państwo, do wykonywania praw i obowiązków spadkobierców powołany był Zarząd Dóbr Państwowych. Na nim ciążył obowiązek dokonania wszystkich formalności, do których zobowiązani byli spadkobiercy nieporządkowi, np. wymóg ubiegania się o wprowadzenie w posiadanie majątku spadkowego ${ }^{65}$.

V. Zgodnie z zasadami przyjętymi w KN spadek po zmarłym miał znaleźć się przede wszystkim w rękach krewnych prawych, a co za tym idzie dopuszczono do dziedziczenia bardzo szeroki ich krąg, do dwunastego stopnia. Przepisy upośledzały natomiast krewnych naturalnych, co było związane z przyjętą koncepcją małżeństwa jako fundamentu rodziny i brakiem akceptacji dla związków nieformalnych. Wśród krewnych prawych na uprzywilejowanej pozycji, tak jak i dziś, znajdowali się zstępni, wyłączając od praw spadowych pozostałych członków rodziny. KN wyłączał w praktyce z kręgu spadkobierców ustawowych małżonka, który dochodził do spadku dopiero w braku krewnych do dwunastego stopnia. Zauważmy, iż KN zakładał wspólność majątkową małżonków, co oznaczało, iż z chwilą śmierci majątek dorobkowy małżonków ulegał podziałowi na dwie części, z których jedna należała się współmałżonkowi pozostałemu przy życiu. Ustawodawca uważał, iż małżonek w ten sposób został zaspokojony.

Wejście w życie w dniu 1 stycznia 1826 r. KCKP w istotny sposób zmieniało zasady dziedziczenia ustawowego, wprowadzając do kręgu spadkobierców ustawowych małżonka (jednocześnie przyjmując między małżonkami jako ustawowy system rozdzielności majątkowej). Nowa regulacja zastrzegała dla współmałżonka prawa spadkowe nawet w sytuacji, gdy do spadku dochodził z zstępnymi, przy czym w tym wypadku otrzymywał on udział spadkowy jedynie na dożywotnie użytkowanie.

${ }^{65}$ M. Planiol, op. cit., s. 73. 
Wprowadzenie przez KCKP do systemu spadkobrania ustawowego małżonka dziedziczącego $\mathrm{w}$ zbiegu z innymi krewnymi, przy braku jednoczesnych nowelizacji przepisów KN spowodowało istotne problemy z określeniem należnych udziałów spadkowych poszczególnym spadkobiercom, zwłaszcza tam, gdzie do spadku dochodził małżonek z krewnymi naturalnymi. Odpowiedź na pytanie, czy przedstawione w niniejszym artykule propozycje wykładni poszczególnych przepisów są trafne, da analiza XIX-wiecznych akt postępowań spadkowych. Badania te mogą być pomocne w rozpatrywaniu współczesnych sporów spadkowych dotyczących spadków otwartych przed rokiem 1947.

\author{
THE RULES OF STATUTORY SUCCESSION \\ IN THE KINGDOM OF POLAND AFTER $1^{\text {ST }}$ JANUARY 1826
}

\title{
Summary
}

The law of succession in the Kingdom of Poland had been governed since 1808 by the Napoleonic Code and since 1 January 1826, additionally regulated by the Civil Code of the Kingdom of Poland (CCKP). The latter kept in force the existing provisions of law but modified the succession rights of spouses. These provisions of law continued in force in central Poland even after the country regained independence in 1918 and were repealed only by the Presidential Decree of 8 October 1946.

The purpose of the study is to review the principal rules of statutory succession that were in force between 1826 and 1946. Under the Napoleonic Code, the estate of the deceased was to devolve mainly upon legitimate relatives, which meant that relatives of up to the $12^{\text {th }}$ degree were allowed to succeed. However, the rules put natural relatives at a disadvantage, which followed from the prevailing concept of marriage as the foundation of a family and the disapproval of informal unions. The coming into force of the CCKP on 1 January 1826 considerably modified the rules of statutory succession by making a spouse a legal heir. The new rules granted a spouse succession rights even when he or she succeeded to the estate jointly with descendants, however in this case the spouse acquired a life interest only.

Under the CCKP, upon intestacy, the spouse was to take jointly with other relatives of the deceased but at the same time no amendments were made to the respective provisions of the Napoleonic Code. In consequence, major problems arose with determining the shares in the estate due to particular successors, especially in cases where the spouse took jointly with natural relatives. 
PRINCIPES DE SUCCESSION LÉGALE SUR LE TERRITOIRE

DU ROYAUME DE POLOGNE APRÈS LE $1^{\text {ER }}$ JANVIER 1826

\section{Résumé}

À partir de 1808, le droit des successions en vigueur sur le territoire du Royaume de Pologne est régi par les dispositions du Code Napoléon $(\mathrm{CN})$, et à partir du $1^{\mathrm{er}}$ janvier 1826, il relèvera du Code civil du Royaume de Pologne (CCRP). Il est vrai que ce dernier laisse en application les dispositions existantes jusqu'à la date susvisée, néanmoins, il change le champ d'application concernant les droits des successsions des époux. Les réglements susmentionnés seront applicables sur le territoire de la Pologne centrale, même lors que le pays aura recouvré son indépendance, et ils seront abrogés seulement le 8 octobre 1946, en vertu du décret présidentiel. L'étude a pour objectif de rappeler les principes majeurs de la succession légale en vigueur durant la période 1826-1946. Conformément aux règles adoptées par le $\mathrm{CN}$, la succession héritée d'un défunt devait revenir avant tout aux parents considérés comme légaux. Par conséquent, aura droit à la succession un cercle très large des parents allant jusqu'au $12^{\mathrm{e}}$ degré. La réglementation en application est cependant un handicap pour les parents proches naturels, cet élément étant lié au concept du mariage considéré comme fondation d'une famille et donc la non acceptation des unions informelles. L'entrée en vigueur, le $1^{\mathrm{er}}$ janvier 1826, du CCRP changera considérablement les principes de la succession légale, car le code introduit l'époux au cercle des héritiers légaux. La nouvelle régulation réservera par ailleurs les droits des successions pour le conjoint, même dans les cas où ce dernier a droit à la succession avec les parents en ligne descendante, sauf qu'en l'occurrence, il obtiendra une quote-part successorale uniquement en usufruit viager.

Le fait que le CCRP a introduit au système de la succession par l'effet de la loi, la succession de l'époux en concours avec d'autres parents et, en parallèle, le manqe des amendements aux dispositions du $\mathrm{CN}$, ont provoqué des contraintes majeures pour la définition des parts successorales de chacun héritier, notamment dans les situations où l'époux parvenait à la succession avec les parents proches nuturels. 